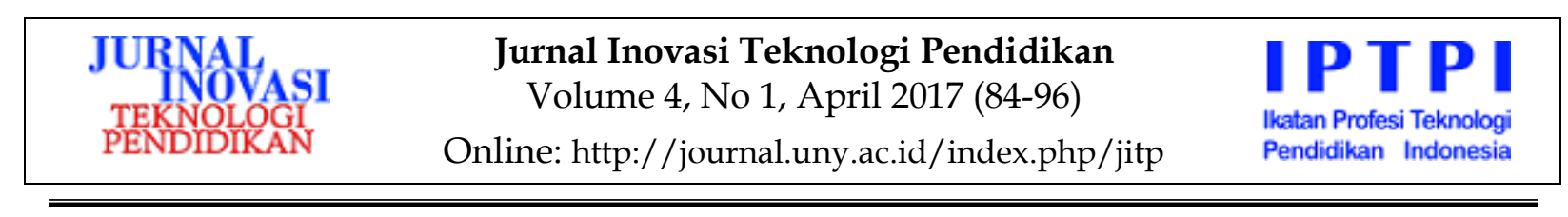

\title{
PENGEMBANGAN DIGITAL BOOK INTERAKTIF MATA KULIAH PENGEMBANGAN MULTIMEDIA PEMBELAJARAN INTERAKTIF UNTUK MAHASISWA TEKNOLOGI PENDIDIKAN
}

\author{
Sella Mawarni, Ali Muhtadi \\ Prodi Teknologi Pembelajaran PPs UNY, Universitas Negeri Yogyakarta \\ sella.edutech@gmail.com, alimuhtadi1@gmail.com
}

\begin{abstract}
Abstrak
Penelitian pengembangan ini bertujuan: (1) menghasilkan produk digital book interaktif yang didesain untuk mata kuliah Pengembangan Multimedia Pembelajaran Interaktif untuk mahasiswa Teknologi Pendidikan FIP UNY, dan (2) mengetahui tingkat kelayakan produk yang dikembangkan. Metode penelitian ini mengacu pada model pengembangan Allesi \& Trollip yang dikelompokkan atas tiga prosedur pengembangan, yakni: (a) planning, (b) design, dan (c) development yang dilengkapi dengan komponen atribut mencakup standards, ongoing evaluation, dan project management. Penelitian ini menghasilkan produk digital book interaktif berupa Compact Disk (CD) berserta buku petunjuk. Hasil skor penilaian kelayakan produk melalui uji alpha pada ahli materi sebesar 3,39 (sangat layak) dan pada ahli media sebesar 3,54 (sangat layak). Selanjutnya pada uji betha kelompok kecil diperoleh skor hasil penilaian sebesar 3,64 (sangat layak) dan pada kelompok besar sebesar 3,37 (sangat layak). Penilaian kelayakan produk pada aspek pembelajaran didukung oleh perolehan rerata skor hasil belajar mahasiswa dan hasil unjuk kerja mahasiswa sesuai capaian pembelajaran.

Kata kunci: digital book interaktif, multimedia pembelajaran interaktif, mahasiswa Teknologi Pendidikan

\section{DEVELOPING INTERACTIVE DIGITAL BOOK FOR "THE DEVELOPMENT OF INTERACTIVE MULTIMEDIA LEARNING COURSE" FOR EDUCATIONAL TECHNOLOGY STUDENTS}

\author{
Sella Mawarni, Ali Muhtadi \\ Prodi Teknologi Pembelajaran PPs UNY, Universitas Negeri Yogyakarta \\ sella.edutech@gmail.com, alimuhtadi1@gmail.com
}

\begin{abstract}
This developmental research aims to: (1) develop an interactive digital book designed for the Development of Interactive Multimedia Learning course for Educational Technology students in faculty of science education Yogyakarta State University, and (2) reveal the feasibility of the developed product. This study refers to the developmental phases developed by Allesi $\mathcal{E}$ Trollip that was grouped into three development procedures, consisting of: (a) planning, (b) design, and (c) development that was equipped with component attributes including standards, ongoing evaluation, and project management. This research has produced interactive digital book in the form of Compact Disk (CD) along with manual. The results of the feasibility assessment scores of products through alpha testing on materials experts are 3.39 (very decent), and the media expert of 3.54 (very decent). Later, the betha test in the small group obtained an assessments score of 3.64 (very decent) and in the large group of 3.37 (very decent). The assessment of the feasibility of the product in the learning aspect is supported by the cognitive learning outcomes and of students performance according to the learning outcomes. Keywords: interactive digital book, interactive multimedia learning, Educational Technology students
\end{abstract}




\section{Pendahuluan}

Tahap adopsi dan adaptasi teknologi telah mengarah pada paradigma "melakukan hal-hal baru dengan cara-cara baru". Munculnya perubahan dan pergeseran paradigma belajar, memberikan dampak pada berbagai aspek pembelajaran diantaranya dalam desain instruksional dan pengembangan media yang perlu berintegrasi dengan perkembangan teknologi. Perkembangan teknologi merupakan salah satu fokus bidang garapan prodi teknologi pendidikan yang terealisasikan dalam bentuk visi dan misi. Program Studi Teknologi Pendidikan FIP UNY memiliki visi di tahun 2025 menjadi pusat pengembang dan pembaru Teknologi Pendidikan yang mandiri dan berwawasan nasionalisme-religius pada 2025 (Program Studi Teknologi Pendidikan FIP UNY, 2014). Profil lulusan yang dihasilkan diharapkan memiliki kemampuan sebagai pranata teknologi pendidikan, pendidik, dan peneliti di bidang teknologi pendidikan.

Sebagai upaya perwujudan visi, prodi Teknologi Pendidikan FIP UNY memiliki beberapa mata kuliah yang output dari mata kuliah tersebut berupa penguasaan keterampilan dalam desain instruksional, pengembangan produk, pemanfaatan dan pengelolaan sumber belajar hingga evaluasi pembelajaran. Pada kurikulum 2014, jenis konsentrasi yang ada di Prodi Teknologi Pendidikan berkembang menjadi 3 jenis, yakni pengembang media pembelajaran, teknologi kinerja, dan pengelola pembelajaran. Mata kuliah konsentrasi ditawarkan mulai dari semester 5 hingga semester 6 . Setiap konsentrasi tentunya membutuhkan sumber belajar. Implikasinya, semakin banyak konsentrasi yang ditawarkan berarti prodi harus menyiapkan tenaga pendidik dan sumber belajar yang memadai.

Pengembangan multimedia pembelajaran interaktif merupakan mata kuliah yang baru diberlakukan untuk angkatan 2014 yang akan mengambil konsentrasi pengembangan media pembelajaran pada semester 6. Karakteristik mata kuliah yang sama, telah diberlakukan pada kurikulum 2009 dengan nama Multimedia Pembelajaran. Berdasarkan hasil survei online (17 23 September 2015) tentang mata kuliah multimedia pembelajaran kepada 19 mahasiswa angkatan 2012 yang sudah memperoleh mata kuliah tersebut, ditemukan data $68,4 \%$ mahasiswa mengalami kesulitan dalam mengembangkan multimedia pembelajaran, dan $78,9 \%$ mahasiswa menyatakan sumber belajar yang tersedia selama perkuliahan kurang memadahi. Dari hasil penelitian Sungkono, Pujiriyanto, \& Hardianto (2010) diketahui bahwa kualitas produk multimedia pembelajaran mahasiswa TP secara keseluruhan baru mencapai angka $69 \%$ berdasarkan kriteria kesesuaian produk dengan penerapan prinsip-prinsip desain multimedia. Sebanyak 78,9\% mahasiswa menyatakan dirinya melakukan praktik mandiri untuk dapat menghasilkan produk multimedia. Selanjutnya, keseluruhan jumlah responden mahasiswa $(100 \%)$ merasa perlu dihadapkan pada praktik latihan yang berbasis tutorial dan simulasi yang memungkinkan percobaan langsung maupun adanya tutorial langkahlangkah penggunaan software-software yang berkaitan dengan pengembangan program multimedia pembelajaran secara terpadu.

Kelengkapan materi perkuliahan dapat ditinjau dari berbagai buku tentang multimedia, namun keberadaan media buku hanya mampu memberikan pemahaman teori, tanpa memberikan fasilitas praktik secara langsung. Sejalan dengan hasil penelitian survei minat baca mahasiswa FIP UNY (Hardianto, 2011) menunjukkan angka $79,20 \%$ yang berarti mahasiswa kadang-kadang memiliki keinginan membaca buku. Seiring dengan perkembangan zaman, buku telah dipadukan dengan alat eletronik sebagai sebuah pengembangan teknologi baru, yaitu ebook. Kini mulai dikembangkan jenis buku digital (digital book) yang lebih menekankan pada aspek interaktivitas dan keterpaduan konten media. Konten digital book dapat terdiri dari 
kombinasi teks, grafis, animasi, suara dan video dalam satu perangkat.

Pemanfaatan sumber belajar digital dinilai dipengaruhi oleh persepsi pendidik tentang digital natives (Dopo \& Ismaniati, 2016 , p. 23). Sumber belajar digital dapat didefinisikan sebagai segala sesuatu dalam format digital yang dapat dimanfaatkan oleh guru dan siswa untuk tujuan pembelajaran (Surjono, 2014, p. 10). Digital book merupakan sumber belajar digital yang fleksibel untuk memfasilitasi kegiatan belajar mahasiswa yang dapat diakses secara klasikal maupun mandiri. Karakteristik digital book diharapkan lebih melibatkan (engage), menginspirasi (inspire), menarik (excite), dan interactive (interaktif) untuk digunakan dalam perkuliahan pengembangan multimedia pembelajaran interaktif dengan tersedianya berbagai jenis media dalam satu perangkat pembelajaran. Teknologi digital dipercaya dapat meningkatkan retensi (retention) dan ketekunan (persistence) belajar pada mahasiswa (Information Resource Management Association, 2012) dan juga dapat memberikan konten yang kaya (rich content) serta lebih cocok untuk diterapkan dalam model pembelajaran abad ke-21.

Digital book interaktif merupakan jenis media terpadu sebab didalamnya dapat mengkolaborasikan keberadaan teks materi, dengan berbagai media seperti video tutorial dan multimedia berbasis simulasi. Karakteristik tersebut sesuai dengan kebutuhan mata kuliah Multimedia Pembelajaran Interaktif, yakni menyediakan sumber belajar terpadu untuk memfasilitasi teori dan praktik. Jenis digital book sebelumnya sudah dikembangkan untuk mendukung pembelajaran sains oleh PesonaEdu berkerjasama dengan Grasindo dan PT Gramedia dalam mengembangkan produk buku digital interaktif GramediaBook $^{\mathrm{TM}}$ yang berisi konten edukasi.

Pengembangan komponen-komponen pembelajaran, seperti media, kurikulum, dan desain instruksional tidak pernah terlepas dari prinsip-prinsip bagaimana siswa belajar sehingga sebelum men- desain media atau multimedia pembelajaran yang efektif, perlu mempertimbangkan kajian teori belajar sebagai dasar pengembangannya. Paradigma teori belajar behavioritsik, kognitif, dan konstruktivistik selanjutnya dapat digunakan secara kolaboratif dan proporsional untuk mendukung terjadinya belajar melalui digital book interaktif. Menurut pendapat Ertmer \& Newby (Rusman, 2012, p. 113) tiga teori belajar tersebut (behavioristik, kognitif, dan konstruktivistik) menjadi dasar dalam pengembangan pembelajaran berbasis Teknologi Informasi dan Komunikasi.

Teori behavioristik memandang belajar adalah perubahan tingkah laku sebagai akibat dari adanya reaksi stimulus dan respon (Budiningsih, 2005, p. 20). Tokoh-tokoh pendukung teori behavioristik diantaranya John B. Watson (1878-1958), Thorndike dengan berbagai teori hukum belajar (readiness, exercise, $\mathcal{E}$ effect), Edwin R. Guthrie melalui konsep reward and punishment (Schunk, 2012, p. 118), dan Skinner sebagai pengusung konsep operant conditioning \& reinforcement. Penerapan teori behavioristik umumnya ditemukan pada perumusan tujuan-tujuan behavioral (perilaku) yang bermula dari perilaku awal kemudian dirumuskan kedalam perilaku yang dikehendaki dari proses belajar siswa. Mager (Schunk, 2012) berpendapat bahwa tujuan behavioral menunjukkan apa yang dilakukan siswa ketika memperlihatkan prestasi mereka dan bagaimana pendidik mengetahui apa yang sedang dilakukan siswa.

Dalam praktek pembelajaran, teori kognitif nampak pada rumusan tahaptahap perkembangan yang dikemukakan oleh J. Piaget, advance organizer oleh Ausubel, pemahaman konsep oleh Bruner dan hierarki belajar oleh Gagne. Gagne mengemukakan konsep teori pemrosesan informasi yang dikembangkan dari psikologi kognitif (Siregar \& Nara, 2014, p. 31) dan konsep nine events of instruction (Butcher, Davies, \& Highton, 2006, p. 81). Digital book ini juga mengadaptasi konsep konstruksi pengetahuan secara mandiri 
dimaknai oleh peserta didik, sesuai dengan teori belajar konstruktivistik. Wray \& Lewis (Pritchard, 2009, p. 28) mengemukakan 4 poin penting pembelajaran menurut teori konstruktivistik, diantaranya: (1) learning is a process of interaction between what is known and what is to be learnt; (2) learning is a social process; (3) learning is a situated process; dan (4) learning is a metacognitive process.

Perkembangan buku digital bukanlah hal yang baru dalam dunia pendidikan. Pada tahun 1990 sudah mulai dikembangkan format open ebook yang memungkinkan pubisher dan pengembang software untuk menggunakan satu format yang dapat dibaca di perangkat manapun dan menggunakan berbagai software pembaca buku digital (SEAMOLEC, 2013). Horizon Report (Johnson, Levine, Smith, \& Stone, 2010, p. 17) menyebutkan ebook sebagai salah satu tren penggunaan teknologi dalam pendidikan tinggi yang akan banyak digunakan dua hingga tiga tahun mendatang (2011 2013). Pada riset selanjutnya, di tahun 2011 Horizon Report (Johnson, Smith, Willis, Levine, \& Haywood, 2011, p. 8) kembali memaparkan bahwa ebook telah banyak digunakan dalam proses pembelajaran dengan respon penggunaan yang positif sebab ebook dinilai sebagai teknologi transformatif yang mampu memberikan berbagai pengalaman baca.

Istilah ebook dapat diartikan secara beragam, dalam Kamus Oxford ebook merupakan "an eletronic version of printed book which can be read on a personal computer" (Noorhidawati \& Gibb, 2008, p. 1). Jones \& Brown (2011, p. 8) kemudian menspesifikasikan ebook ke dalam dua format penyajian, yakni online websites yang tersaji dalam jaringan secara online dan personal eletronic device yakni telah tersimpan dalam perangkat tanpa perlu koneksi internet. Praktik pemanfaatan sumber belajar berupa ebook pada level pendidikan tinggi, dapat dikelompokkan berdasarkan fungsi atau tujuan penggunaannya yakni: (1) fact finding merupakan penggunaan ebook untuk mencari bagian spesifik dari sebuah informasi/fak- ta; (2) finding relevant content; merupakan penggunaan ebook untuk mencari potongan informasi yang dibutuhkan misalnya pencarian buku-buku perkuliahan, prosiding serta jurnal; dan (3) extended reading yang bertujuan untuk memperoleh informasi mendalam misalnya ebook yang berisi satu mata kuliah (Shiratuddin, Landoni, Gibb, \& Hassan, 2003). Menurut Shiratuddin et al. (2003), praktik pemanfaatan sumber belajar berupa ebook pada level pendidikan tinggi, dapat dikelompokkan berdasarkan fungsi atau tujuan penggunaannya yakni: (1) fact finding merupakan penggunaan ebook untuk mencari bagian spesifik dari sebuah informai/fakta; (2) finding relevant content; merupakan penggunaan ebook untuk mencari potongan informasi yang dibutuhkan misalnya pencarian buku-buku perkuliahan, prosiding serta jurnal; dan (3) extended reading yang bertujuan untuk memperoleh informasi mendalam misalnya ebook yang berisi satu mata kuliah. Berdasarkan pada hasil penelitian Noorhidawati \& Gibb (2008, p. 2008) diperoleh kesimpulan bahwa sebagian besar mahasiswa mempergunakan ebook untuk mencari materi yang relevan dengan proyek atau esai atau dengan kata lain penggunaan ebook ditujukan untuk mendukung kinerja tugas mereka secara spesifik (finding relevant content). Format ebook yang ada seharusnya mampu mengakomodir fungsi-fungsi tersebut, agar kebutuhan belajar mahasiswa dapat terpenuhi dalam satu sajian ebook yang multifungsi.

Digital book juga dapat digolongkan dalam konten digital (publication) dan kombinasi software dan hardware untuk menghasilkan produk buku digital yang berisi konten-konten multimedia. Pengembangan digital book tidak terlepas dari penerapan konsep pengembangan modul dan multimedia pembelajaran, yang membentuk digital book sebagai modul terpadu yang berisi konten multimedia yang berkolaboarasi secara interaktif. Digital book dapat disebut sebagai comprehensive handout, yakni memberikan materi secara keseluruhan mencakup satu materi dari awal hingga 
akhir (Butcher et al., 2006, p. 142). Sedangkan prinsip-prinsip multimedia yang digunakan dalam pengembangan digital book diadaptasi dari 7 prinsip multimedia oleh Mayer (2009).

Melalui sistem modul sangat dimungkinkan siswa lebih termotivasi untuk belajar. Selain itu modul memfasilitasi individual learning sehingga kemajuan siswa dapat dikontrol oleh siswa itu sendiri sesuai dengan kemampuannya. Karakteristik modul yang dapat diterapkan pada digital book interaktif antara lain prinsip: selfinstructional, self-contained, stand-alone, adaptive, dan user friendly. Self-instructional berarti modul sebagai bahan ajar yang mampu dipelajari secara mandiri dan terdiri dari komponen-komponen instruksional yang mampu mendukung proses belajar (standar kompetensi, materi, soal latihan, rangkuman, dan lain sebagainya). Self-contained yakni memberikan kesempatan kepada peserta didik mempelajari materi pembelajaran yang dikemas dalam satu kesatuan yang utuh. Stand-alone yang berarti modul yang dikembangkan sebaiknya tidak bergantung pada media lain, atau tidak harus digunakan bersama-sama media lain sehingga mempersulit siswa untuk belajar. Adaptive, berarti modul hendaknya memiliki daya adaptasi yang tinggi terhadap perkembangan ilmu dan teknologi. User friendly berarti modul hendaknya juga memenuhi kaidah user friendly atau mudah digunakan oleh pebelajar. Penggunaan bahasa yang sederhana, mudah dimengerti, dan penggunaan istilah yang umum merupakan salah satu bentuk user friendly.

Digital book merupakan sebuah kolaborasi konten antara modul, piranti digital, dan penggunaan berbagai jenis media pendukung yang menambah daya interaktivitas. Adapun salah satu keunggulan multimedia pembelajaran yang dikemukakan oleh Aster (Winarno et al., 2009, p. 10) yakni penggunaan multimedia dalam pembelajaran dapat memfasilitasi belajar mandiri atau pun secara berkelompok. Multimedia lebih tepat digunakan untuk mengajarkan materi baru yang sifatnya mem- butuhkan praktik (simulasi dan tutorial). Melalui penggunaan multimedia, pebelajar dapat segera mendapatkan feedback secara lebih cepat untuk menilai kemampuan belajarnya. Adapun prinsip-prinsip multimedia menurut Mayer (2009) yang dirujuk sebagai prinsip pengembangan digital book interaktif mencakup prinsip: (1) multimedia, (2) keterdekatan ruang (spatial contiguity principle), (3) keterdekatan waktu (temporal contiguity principle), (4) koherensi, (5) modalitas, (6) redundansi, dan prinsip (7) perbedaan individual.

Kolaborasi antara modul dan multimedia menjadi sebuah digital book merupakan langkah kombinasi untuk menghasilkan bahan ajar yang mampu memfasilitasi pebelajar secara holistik. Bersifat menyeluruh, baik yang terkait dengan konten maupun karakteristik tampilannya. Kelebihan dari aspek modul dan multimedia dapat memberikan beragam pengalaman belajar ketika keduanya didesain sesuai dengan prinsipnya masing-masing.

Pengembangan digital book juga memperhatikan karakteristik mata kuliah dan karakteristik pengguna yakni para mahasiswa yang dapat digolongkan kedalam kategori pebelajar orang dewasa. Beberapa karakteristik belajar pada orang dewasa yang perlu diperhatikan yakni (Knowles, Holton III, \& Swanson, 2005, p. 40): (1) the need to know; (2) the learner self-concept; (3) the role of the learners' experience; (4) readiness to learn; (5) orientation to learning; dan (6) motivation. Ke-6 prinsip tersebut selanjutnya dikolaborasikan dalam mendesain konten digital book yang tepat sesuai dengan krakteristik penggunanya.

Untuk mengevaluasi produk digital book diperlukan instrumen evaluasi yang mampu mengemas keseluruhan aspek yang perlu dinilai. Evaluasi digital book juga tidak terlepas dari komponen-komponen penyusun yang ada di dalamnya, sebab dari masing-masing komponen tersebut dapat diidentifikasi indikator-indikator apa saja yang harus dievaluasi. Instumen evaluasi yang diperlukan untuk menilai kualitas dan kelayakan digital book setidaknya 
mencakup aspek komponen modul pembelajaran dan multimedia. Instrumen evaluasi digital book dikembangkan berdasarkan pada referensi beberapa instrumen hasil penelitian. Pertama, instrumen evaluasi modul pembelajaran yang dihasilkan dari penelitian Sungkono (2012) berjudul "Pengembangan Instrumen Evaluasi Media Modul Pembelajaran". Dari hasil penelitian tersebut, aspek-aspek instrumen evaluasi diantaranya mencakup: (1) kelengkapan identitas, (2) aspek bahasa, (3) kejelasan petunjuk, (4) aspek fisik, (5) aspek pendahuluan, (6) aspek isi, (7) aspek tugas, dan (8) aspek rangkuman.

Kedua, instrumen evaluasi program multimedia pembelajaran oleh John Wiley \& Sons yang dikutip dalam buku Lee \& Owens (2004) dengan judul MultimediaBased Instructional Design. Dari hasil penelitian tersebut, aspek-aspek instrumen evaluasi diantaranya mencakup aspek: (1) registration/interface design, (2) course design/ content, (3) quality and use of media, dan (4) connectivity and download speed. Ketiga, instrumen evaluasi program multimedia pembelajaran oleh Ivers \& Barron (2002) dalam bukunya yang berjudul Multimedia Project in Education: Designing, Producing, and Assessing. Dalam buku tersebut dijelaskan beberapa aspek-aspek penilaian sekaligus rubrik penilaian yang diantaranya mencakup: (1) content, (2) technical, (3) design, dan (4) presentation. Keempat, instrumen evaluasi program multimedia pembelajaran oleh Mishra \& Reddi (2003) dalam bukunya yang berjudul Educational Multimedia. Dalam buku tersebut disebutkan beberapa aspek-aspek penilaian secara rinci namun tidak dikelompokkan berdasarkan pada sub indikator seperti pada penelitian-penelitian sebelumnya. Apabila dianalisis kedalam pengelompokkan subsub aspek penilaian, aspek-aspek instrumen evaluasi diantaranya mencakup: (1) aspek content expert questionnaire yang terdiri dari sub course content, media, graphics, dan delivery strategy, dan (2) aspek learner questionnaire yang terdiri dari sub access to computers, familiarity with computers, fami- liarity with use of computers for education/learning, course content, media, graphics, dan delivery strategy.

Penelitian ini dibatasi pada permasalahan belum dikembangkannya media pembelajaran yang bersifat simulasi dan tutorial yang sesuai untuk karakteristik mata kuliah Pengembangan Multimedia Pembelajaran Interaktif. Oleh karena itu, diperlukan pengembangan produk digital book yang didalamnya membahas materi pengembangan multimedia pembelajaran berbasis tutorial dan simulasi serta dilengkapi dengan berbagai konten media untuk mahasiswa Teknologi Pendidikan FIP UNY. Adapun masalah yang diteliti dirumuskan sebagai berikut: (1) bagaimana menghasilkan produk digital book interaktif yang didesain untuk mata kuliah Pengembangan Multimedia Pembelajaran Interaktif untuk mahasiswa Teknologi Pendidikan FIP UNY, dan (2) bagaimana kelayakan produk digital book interaktif mata kuliah Pengembangan Multimedia Pembelajaran Interaktif untuk mahasiswa Teknologi Pendidikan FIP UNY.

\section{Metode Penelitian}

Penelitian ini menggunakan pendekatan kuantitatif dengan jenis penelitian pengembangan Research and Development (R\&D) yang mengacu pada model pengembangan Alessi \& Trollip (2001). Model pengembangan Alessi dan Trollip memiliki komponen yang terdiri dari langkah-langkah pengembangan (planning, design, $\mathcal{E}$ development) serta atribut yang selalu ada dalam setiap tahap. Komponen atribut tersebut mencakup standar (standards), evaluasi berkelanjutan (ongoing evaluation), dan manajemen proyek (project management) yang menjadi pelengkap dan bahan pertimbangan dalam mengembangkan produk.

Penelitian ini dilaksanakan selama Bulan September 2015 sampai dengan Mei 2016. Penelitian dilakukan di Jurusan Kurikulum dan Teknologi Pendidikan Fakultas Ilmu Pendidikan Universitas Negeri Yog- 
yakarta. Subjek atau responden yang terlibat dalam penelitian ini adalah mahasiswa Teknologi Pendidikan Universitas Negeri Yogyakarta, yang berjumlah 6 orang untuk uji alpha dan 28 orang untuk dilakukan uji beta dan memperoleh penilaian respon digital book interaktif dari sisi pengguna.

Prosedur

Sebelum melakukan pengembangan produk, dilakukan analisis kebutuhan untuk menentukan karakteristik materi yang akan dibuat. Analisis ini mengacu pada kurikulum yang berlaku di Prodi Teknologi Pendidikan UNY untuk tahun ajaran 2014/2015. Selanjutnya, prosedur pengembangan digital book interakif adalah mengikuti tahap-tahap pengembangan planning, design, dan development. Tahap perencanaan berisi kajian awal yang berkaitan dengan kegiatan analisis kebutuhan. Pada tahap desain, mulai dikembangkan prototype beserta flowchart, storyboard dan analisis instruksional. Tahap pengembangan berkaitan dengan eksekusi teknis yang berkaitan dengan mempersiapkan komponen-komponen media dan konten untuk dipadukan menjadi satu kesatuan dalam produk digital book interaktif. Selanjutnya untuk menilai tingkat kelayakan produk, dilakukan uji coba yang terdiri dari uji alpha dan uji betha. Uji alpha dilakukan oleh 2 ahli materi dan 2 ahli media untuk menilai kelayakan dari segi konten dan media. Uji betha dilakukan melalui 2 tahap, yakni uji kelompok kecil kepada 6 mahasiswa dan uji kelompok besar pada 28 mahasiswa semester 6 prodi Teknologi Pendidikan FIP UNY. Instrumen penilaian yang digunakan akan terlebih dahulu divalidasi oleh satu orang ahli dibidangnya.

Teknik pengumpulan data yang digunakan dalam penelitian ini berupa tes, kuisioner, observasi, dan dokumentasi. Sedangkan instrumen yang digunakan adalah angket, tes hasil belajar mata kuliah Pengembangan Multimedia Pembelajaran Interaktif, dan lembar unjuk kerja mahasiswa (checklist). Instrumen angket terdiri dari empat jenis, yaitu angket untuk analisis kebutuhan, angket ahli materi, ahli media, dan untuk pengguna (user) yang digunakan untuk menilai tingkat kelayakan produk dari aspek tertentu. Angket didesain dalam empat skala penilaian dari range "Sangat Kurang" (1), "Kurang" (2), "Baik" (3), hingga "Sangat Baik" (4).

Angket untuk ahli materi terdiri dari penilaian aspek pendahuluan, isi, pembelajaran (kurikulum), latihan/tugas, dan aspek rangkuman. Angket untuk ahli media meliputi penilaian pada aspek desain tampilan, pemrograman dan pemanfaatan digital book interaktif. Pada angket untuk pengguna (mahasiswa) digunakan untuk mengetahui respon mahasiswa terhadap kualitas tampilan, pemrograman dan penyajian materi (pembelajaran) digital book interaktif. Instrumen tes dan unjuk kerja digunakan untuk menilai hasil belajar kognitif mahasiswa setelah menggunakan produk digital book interaktif.

Teknik analisis data yang digunakan dalam mengolah data yang diperoleh dalam penelitian ini menggunakan teknik analisis data kualitatif, yaitu analisis data deskriptif kualitatif untuk kelayakan media dan pengaruh media terhadap hasil belajar. Untuk mengubah skor penilaian kedalam data kualitatif, maka digunakan pedoman skala penilaian instrumen dan kriteria penilaian instrumen yang dapat dilihat pada tabel 1, 2, dan 3 (Mardapi, 2008, p. 123).

Tabel 1. Pedoman Skala Penilaian Skor Instrumen

\begin{tabular}{cc}
\hline Data Kuantitatif & Penilaian \\
\hline Sangat Baik & 4 \\
Baik & 3 \\
Kurang & 2 \\
Sangat Kurang & 1 \\
\hline
\end{tabular}

Tabel 2. Kriteria Penilaian Total Skor Instrumen

\begin{tabular}{ccc}
\hline Rentang Skor & Nilai & Kategori \\
\hline $\mathrm{x} \geq \bar{x}+1 \mathrm{SBi}$ & 4 & Sangat Layak \\
$\bar{x}+1 \mathrm{SBi}>\mathrm{x} \geq \bar{x}$ & 3 & Layak \\
$\bar{x}>\mathrm{x} \geq \bar{x}-1 \mathrm{SBi}$ & 2 & Kurang Layak \\
$\mathrm{x}<\bar{x}-1 \mathrm{SBi}$ & 1 & Sangat Kurang Layak \\
\hline
\end{tabular}


Tabel 3. Tabel 3.Perhitungan Kriteria Penilaian Skor Total Instrumen

\begin{tabular}{ccc}
\hline Rentang Skor & Nilai & Kategori \\
\hline $\mathrm{x} \geq \bar{x}+1 \mathrm{SBi}$ & 4 & Sangat Layak \\
$\bar{x}+1 \mathrm{SBi}>\mathrm{x} \geq \bar{x}$ & 3 & Layak \\
$\bar{x}>\mathrm{x} \geq \bar{x}-1 \mathrm{SBi}$ & 2 & Kurang Layak \\
$\mathrm{x}<\bar{x}-1 \mathrm{SBi}$ & 1 & Sangat Kurang Layak \\
\hline
\end{tabular}

Untuk memperoleh data tentang manfaat digital book untuk meningkatkan kompetensi mahasiswa TP dalam menghasilkan produk multimedia pembelajaran, dapat diketahui melalui hasil tes dan unjuk kerja mahasiswa. Apabila skor mahasiswa mencapai $>75 \%$ dari skor keseluruhan dapat dikatakan bahwa tujuan instruksional umum mata kuliah pengembangan multimedia pembelajaran interaktif telah tercapai.

\section{Hasil Penelitian dan Pembahasan}

Pada tahap analisis kebutuhan atau dapat disebut tahap define the scope dan identify learner characteristic yang ada pada tahap perencanaan (planning), dilakukan survei online yang telah diisi oleh 19 responden. Untuk mengetahui jenis media seperti apa yang dibutuhkan oleh mahasiswa, pada butir terakhir isntrumen analisis kebutuhan, responden dapat memilih satu dari 4 alternatif pilihan media, sehingga diperoleh hasil 17 mahasiswa (89\%) memilih format media terpadu yang terdiri dari 3 jenis media (buku, video, dan simulasi) dan 2 mahasiswa lainnya (11\%) memilih jenis media berbasis simulasi yang ditunjukkan dalam diagram Gambar 1.

Pada tahap uji alpha oleh dua orang ahli materi, diperoleh kesimpulan bahwa produk digital book interaktif ini sangat layak untuk uji coba lapangan dengan revisi sesuai saran. Rerata skor keseluruhan yang diperoleh dari 5 aspek penilaian oleh 2 orang ahli materi, diperoleh angka 3,39 yang secara kualitatif masuk dalam kategori "Sangat Layak" ( $X \geq 3,1)$. Rerata skor untuk penilaian pada aspek pendahuluan sebesar 3,25; aspek isi sebesar
3,44; aspek pembelajaran (kurikulum) sebesar 3,68; aspek rangkuman sebesar 3,5; dan aspek tugas/latihan sebesar 3,08. Rangkuman penialain keseluruhan dari kedua ahli materi dapat dilihat pada diagram Gambar 2.

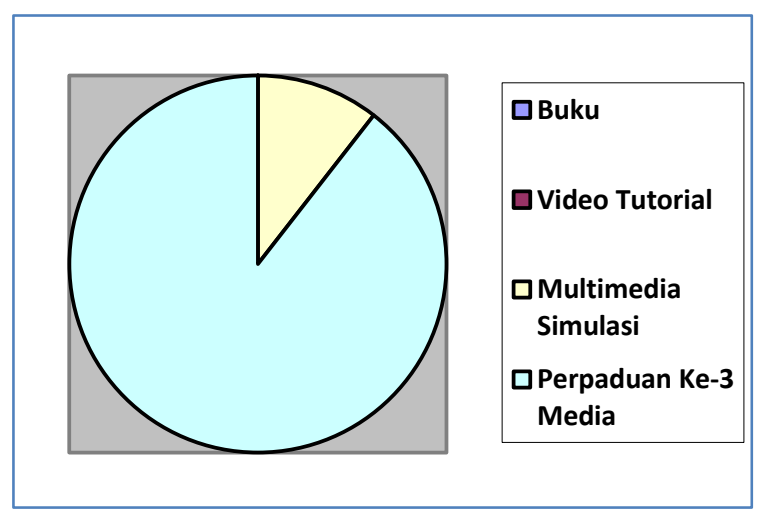

Gambar 1. Jenis Media yang Dipilih Mahasiswa TP

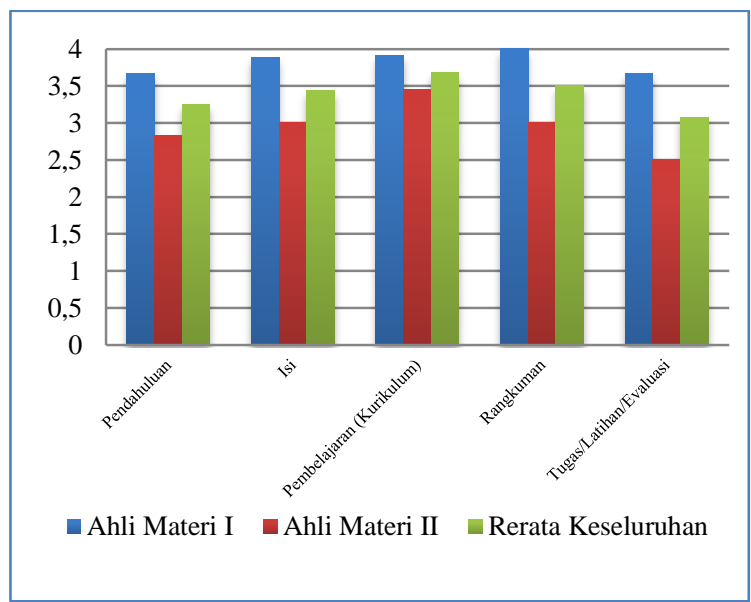

Gambar 2. Diagram Batang Hasil Penilaian Ahli Materi

Pada tahap uji alpha oleh dua orang ahli media, diperoleh kesimpulan bahwa produk digital book interaktif ini sangat layak untuk uji coba lapangan dengan revisi sesuai saran. Rerata skor keseluruhan yang diperoleh dari 4 aspek penilaian oleh 2 orang ahli media, diperoleh angka 3,54 yang secara kualitatif masuk dalam kategori Sangat Layak ( $X \geq 3,1$ ). Rerata skor untuk penilaian pada aspek desain sebesar 3,45; aspek tampilan sebesar 3,59; aspek pemrograman sebesar 3,69 ; dan aspek pemanfaatan sebesar 3,42. Rangkuman 
penialain keseluruhan dari kedua ahli media dapat dilihat pada diagram Gambar 3.

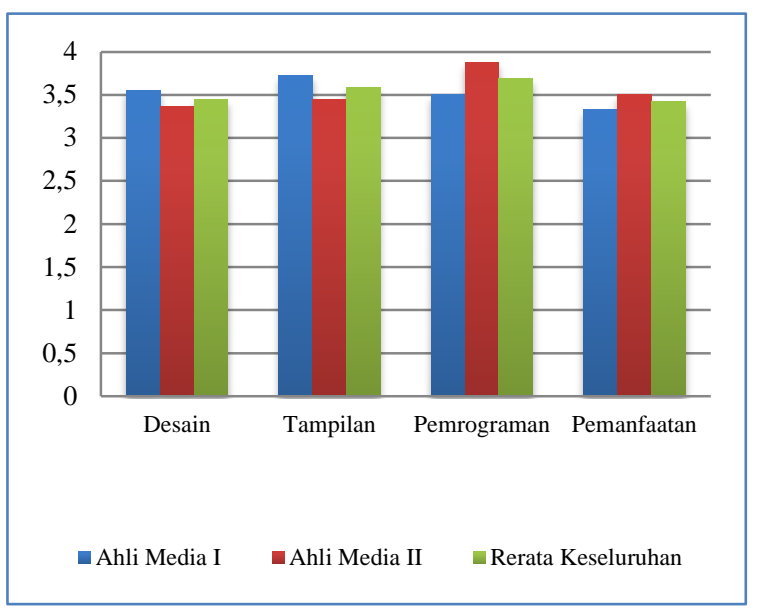

Gambar 3. Diagram Batang Hasil Penilaian Ahli Media

Pada tahap uji betha kelompok kecil (6 mahasiswa), diperoleh kesimpulan bahwa produk digital book interaktif ini sangat layak untuk uji coba lapangan dengan revisi sesuai saran. Rerata skor keseluruhan yang diperoleh dari 3 aspek penilaian adalah 3,63 yang secara kualitatif masuk dalam kategori "Sangat Layak" ( $X$ $\geq 3,1$ ). Rerata skor untuk penilaian pada aspek pembelajaran sebesar 3,70; aspek tampilan sebesar 3,57; dan aspek pemrograman sebesar 3,63. Rangkuman penialain keseluruhan dari uji kelompok kecil dapat dilihat pada diagram Gambar 4.

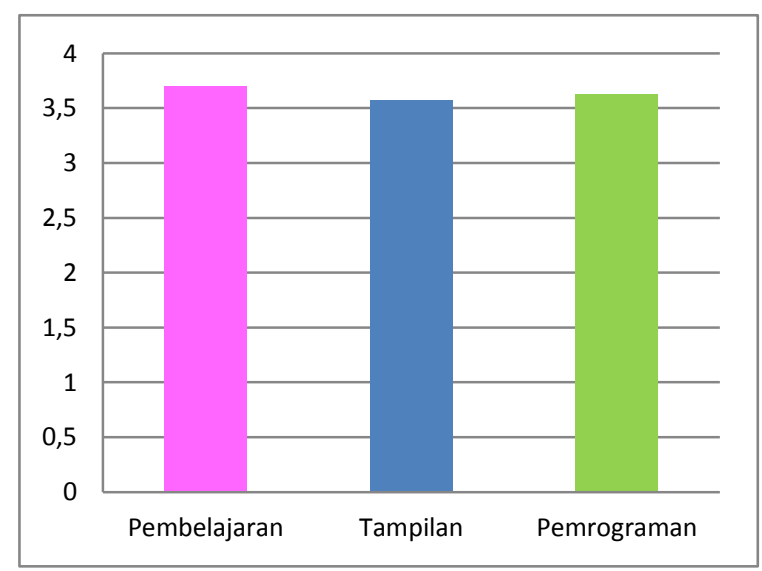

Gambar 4. Diagram Batang Hasil Penilaian Uji Kelompok Kecil

Pada tahap uji betha kelompok besar (28 mahasiswa), diperoleh kesimpulan bahwa produk digital book interaktif ini sangat layak untuk uji coba lapangan dengan revisi sesuai saran. Rerata skor keseluruhan yang diperoleh dari 3 aspek penilaian adalah 3,37 yang secara kualitatif masuk dalam kategori "Sangat Layak" ( $X$ $\geq 3,1$ ). Rerata skor untuk penilaian pada aspek pembelajaran sebesar 3,34; aspek tampilan sebesar 3,37; dan aspek pemrograman sebesar 3,39. Rangkuman penialain keseluruhan dari uji kelompok besar dapat dilihat pada diagram Gambar 5.

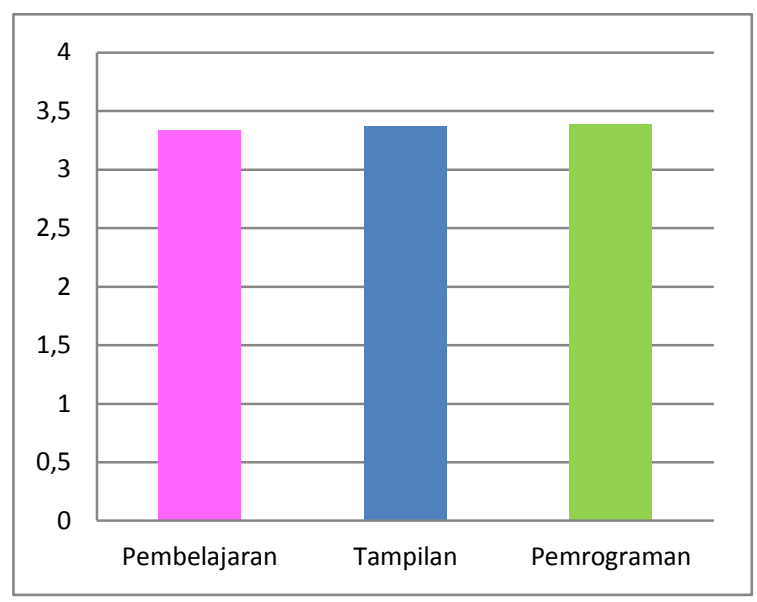

Gambar 5. Diagram Batang Hasil Penilaian Uji Kelompok Besar

Untuk menilai tingkat kebermanfaatan produk digital book interaktif dalam meningkatkan hasil belajar kognitif mahasiswa, digunakan instrumen tes dan lembar praktik unjuk kerja. Instrumen tes merupakan tes latihan/kuis yang ada dalam bab digital book interaktif. Saat dilaksanakan uji coba kelompok besar, mahasiswa memilih dua bab untuk dipelajari bersama yakni Bab 3 tentang Prinsip-Prinsip Pengembangan Multimedia Pembelajaran Interaktif dan Bab 11 tentang Praktik Mandiri Pengembangan Multimedia Pembelajaran Interaktif. Pada akhir bab 3, mahasiswa diminta mengerjakan 10 butir soal latihan, sedangkan pada bab 11 mahasiswa melakukan praktik unjuk kerja sesuai dengan tahap-tahap latihan yang ada pada digital book interaktif. Skor ketuntasan minimal untuk soal tes adalah $75 \%$, sedangkan penilaian praktik unjuk kerja dinilai dari output produk yang dihasilkan mahasiswa 
berdasarkan kriteria langkah-langkah yang terpenuhi.

Dari data skor tes mahasiswa, diketahui bahwa rerata keseluruhan yang diperoleh adalah 80,7 dan berada diatas kriteria ketuntasan minimal $(X>75)$ sehingga dapat disimpulkan bahwa penggunaan digital book memberikan manfaat bagi mahasiswa sebagai sumber belajar mata kuliah Multimedia Pembelajaran. Penilaian praktik unjuk kerja dilakukan secara berkelompok (yang terdiri dari maksimal 2 orang) untuk menghasilkan produk animasi menggunakan Adobe/Macromedia Flash. Terdapat tiga kompetensi utama yang harus dipenuhi dalam penilaian praktik unjuk kerja, yakni: (a) menambahkan tombol (button) baik yang dibuat sendiri ataupun menggunakan tombol bawaan yang ada di library kedalam stage; (b) membuat materi atau konten dalam bentuk frame by frame; dan (c) menggunakan action script gotoAndPlay untuk menghubungkan fungsi tombol (button) dengan materi atau konten yang berkaitan. Selama proses latihan praktik membuat animasi menggunakan Adobe/Macromedia Flash, mahasiswa membaca dan mengikuti langkah-langkah yang ada dalam digital book interaktif tanpa bantuan fasilitator (peneliti) atau pun dosen, hal ini sesuai dengan asumsi pembelajaran orang dewasa menurut Lindeman yakni adults have a deep need to be selfdirecting (Knowles et al., 2005, p. 40).

Keunggulan digital book interaktif didukung oleh konten yang didesain untuk memberikan pembelajaran yang bermakna milik Bruner, yakni memberikan kesempatan kepada mahasiswa untuk aktif mengidentifikasi prinsip-prinsip kunci yang ditemukannya sendiri, bukan hanya sekedar menerima penjelasan. Untuk mendukung hal tersebut, maka aspek penyusunan konten materi didukung menggunakan teori urutan kegiatan belajar yang dikemukakan oleh Gagne dalam nine events of instruction. Digital book interaktif ini dinilai mampu menstimuli berpikir divergen melalui penyajian konten yang berupa tutorial, ilustrasi, dan simulasi didalamnya.
Pada prinsipnya, digital book interaktif ini dikembangkan berdasarkan pada acuan karakteristik modul yakni: (a) selfinstructional, (b) self-contained, c) stand-alone, (d) adaptive, dan (e) user friendly. Tampilan dan navigasi yang ada dalam produk gital book interaktif didesain mengikuti pola bu$\mathrm{ku}$ teks yang sederhana dan mudah dioperasikan oleh mahasiswa dan juga dilengkapi dengan navigasi tambahan sesuai fasilitas buku konvensional namun lebih praktis dalam penggunaannya. Misalnya, tersedianya fitur daftar isi (table of content) digital, kolom pencarian teks, zoom, dan print yang dapat dikases dengan mudah (user friendly) oleh mahasiswa.

Dapat disimpulkan bahwa perolehan skor penilaian digital book interaktif secara keseluruhan berada pada kategori "Sangat Layak" yang berarti produk tersebut sangat layak dari aspek media, materi, maupun pengguna (user). Dari aspek pengguna, penyusunan konten yang ada ada digital book interaktif telah disesuikan dengan pola berpikir mahasiswa sehingga mampu mengembangkan pemahaman mereka dari konsep teoritis kedalam bentuk latihan praktik. Menurut Knowles et al. (2005) mahasiswa merupakan pebelajar orang dewasa yang memerlukan pola pembelajaran yang mampu memenuhi prinsip-prinsip belajar orang dewasa yakni the need to know, the learner self-concept, the role of the learner experience, readiness to learn, orientation to learning, dan motivation. Prinsip-prinsip belajar tersebut diterjemahkan kedalam digital book melalui urutan proses pengembangan yang dimulai dari mengidentifikasi capaian pembelajaran, menentukan garis besar materi, menuliskan berbagai konten materi dari berbagai sumber, hingga pada penentuan format dan tata letak agar sesuai dengan bagaimana mahasiswa dapat belajar secara optimal.

Selanjutnya dari aspek media, produk digital book interaktif menyajikan berbagai format media (multimedia) seperti teks, gambar, video, animasi, dan tutorial yang mampu memberikan beragam pengalaman belajar kepada mahasiswa (learner 
experience). Dari aspek materi, konten materi yang ada didalam digital book interaktif disusun dari beragam sumber referensi yang kemudian dikemas sesuai dengan prinsip-prinsip teori belajar agar mampu mencapai tujuan pembelajaran secara optimal.

Setelah dilakukan uji coba dan kajian mengenai produk akhir digital book interaktif, dapat ditemukan beberapa aspek kelemahan atau kekurangan dari produk tersebut diantaranya: (1) produk digital book interaktif berisi latihan/kuis yang dikembangkan menggunakan program tersendiri (iSpring Quiz Maker) sehingga untuk format digital book tertentu (.exe dan .html) tidak bisa dilakukan load (memanggil file kuis), sedangkan pada format .swf kuis dapat di load namun terkadang mengalami crush atau gangguan pada tampilannya. Hal tersebut masih bisa diatasi dengan penyediaan file kuis yang dapat dibuka secara terpisah dari file digital book interaktif; (2) semakin banyak konten yang dimuat didalam digital book interaktif (terutama konten video dan animasi) berdampak pada semakin besarnya ukuran file output dari digital book interaktif. Hal ini akan berdampak pada komputer/notebook dengan spec rendah; (3) format produk digital book interaktif yang dikembangkan hanya tersedia dalam format baca layar komputer/notebook, perlu dikembangkan dalam format baca lain misalnya untuk perangkat smartphone Android dan iOS yang dapat dilakukan pada penelitian-penelitian selanjutnya.

\section{Simpulan}

Berdasarkan pada rumusan masalah, tujuan penelitian, pertanyaan penelitian, serta pembahasan hasil penelitian dan pengembangan produk digital book interaktif, maka dapat diperoleh kesimpulan sebagai berikut: Pertama, Produk digital book interaktif yang dihasilkan berupa kepingan Compact Disk (CD) berserta buku petunjuk (manual) yang dapat digunakan sebagai sumber belajar mata kuliah Pe- ngembangan Multimedia Pembelajaran Interaktif untuk mahasiswa TP FIP UNY baik secara individual maupun klasikal atau berkelompok. Produk digital book interaktif yang dihasilkan, memiliki desain tampilan umum seperti sebuah buku teks pada umumnya, namun konten didalamnya terdiri dari berbagai komponen media yakni teks, gambar, video, animasi, berbagai fitur tombol, dan menggunakan proporsi warna yang menarik untuk mahasiswa. Produk digital book interaktif ini terdiri atas beberapa komponen isi, diantaranya: (a) halaman sampul (cover), (b) halaman identitas buku, (c) kata pengantar, (d) daftar isi, (e) informasi sasaran pengguna dan mata kuliah, (f) sub cover pada setiap bab, (g) konten materi, (h) rangkuman, (i) latihan/tugas/evaluasi, (j) daftar pustaka, dan (k) identitas pengembang. Desain evaluasi yang ada dalam digital book interaktif mencakup latihan soal dalam bentuk tes yang terdiri dari berbagai jenis tes, yakni pilihan ganda, true/false, multiple responses, dan rearrangement test (tes menyusun kembali urutan) serta latihan praktik disertai contoh hasil animasi dari langkah-langkah tutorial yang diberikan. Kedua jenis evaluasi tersebut sesuai dengan capaian pembelajaran mata kuliah multimedia pembelajaran, yakni mahasiswa diharapkan dapat memahami konsep sekaligus mampu menghasilkan atau mengembangkan sebuah produk multimedia pembelajaran interaktif.

Kedua, hasil uji kelayakan berdasarkan hasil alpha test dan betha test adalah sebagai berikut: (a) hasil alpha test dari kedua ahli materi diperoleh rerata skor keseluruhan sebesar 3,39 dengan kategori "Sangat Layak", (b) hasil alpha test dari kedua ahli media diperoleh rerata skor keseluruhan sebesar 3,54 dengan kategori "Sangat Layak", (c) hasil betha test pada uji kelompok kecil diperoleh rerata skor keseluruhan sebesar 3,63 dengan kategori "Sangat Layak", dan (d) hasil betha test pada uji kelompok besar diperoleh rerata skor keseluruhan sebesar 3,37 dengan kategori "Sangat Layak". 
Berdasarkan simpulan hasil penelitian, maka dapat disampaikan saran yaitu untuk mengoperasikan file digital book interaktif sebaiknya menggunakan komputer atau notebook dengan spec sesuai dengan pesyaratan minimal sistem yang telah dijelaskan dalam manual (buku panduan). Produk digital book interaktif juga tersedia juga dalam jenis file $\mathrm{html}$ yang dapat dimanfaatkan sebagai sumber belajar pendukung untuk LMS (Learning Management System) seperti Moodle, website pembelajaran, dan lain sebagainya. Sebaiknya gunakan perangkat input tambahan berupa mouse untuk mempermudah kontrol pengguna dalam menggunakan fitur zoom in/out terkait dengan ukuran keterbacaan huruf dan kejelasan tampilan.

\section{Daftar Pustaka}

Alessi, S. M., \& Trollip, S. P. (2001). Multimedia for learning: methods and development (3rd ed.). Boston: Allyn and Bacon.

Budiningsih, C. A. (2005). Belajar dan pembelajaran. Jakarta: Rineka Cipta.

Butcher, C., Davies, C., \& Highton, M. (2006). Designing learning: from module outline to effective teaching. New York: Routledge.

Dopo, F. B., \& Ismaniati, C. (2016). Persepsi guru tentang digital natives, sumber belajar digital dan motivasi memanfaatkan sumber belajar digital. Jurnal Inovasi Teknologi Pendidikan, 3(1), 13-24. https://doi.org/10.21831/tp.v3i1.828 0

Hardianto, D. (2011). Studi tentang minat baca mahasiswa Fakultas Ilmu Pendidikan UNY. Majalah Ilmiah Pembelajaran, 7(1), 108-121. Retrieved from

http://journal.uny.ac.id/index.php/ $\mathrm{mip} /$ article/view/3218

Ivers, K. S., \& Barron, A. E. (2002). Multimedia projects in education:
Designing, producing, and assessing. Englewood, CO: Libraries Unlimited.

Johnson, L., Levine, A., Smith, R., \& Stone, S. (2010). The 2010 horizon report. Asutin, Texas: The New Media Consortium.

Johnson, L., Smith, R., Willis, H., Levine, A., \& Haywood, K. (2011). The 2011 horizon report. Austin, Texas: The New Media Consortium.

Jones, T., \& Brown, C. (2011). Reading engagement: a comparison between ebooks and traditional print Books in an elementary classroom. International Journal of Instruction, 4(2). Retrieved from http://www.eiji.net/dosyalar/iji_2011_2_1.pdf

Knowles, M. S., Holton III, E. F., \& Swanson, R. A. (2005). The adult learner: the definitive classic in adult education and human resource development. The Adult Learner (6th ed.). New York: Elsevier.

Lee, W. W., \& Owens, D. L. (2004). Multimedia-based instructional design: computer-based training, web-based training, distance broadcast training, performance-based solutions (2nd ed.). San Francisco: Pfeiffer.

Mardapi, D. (2008). Teknik penyusunan instrumen tes dan nontes. Yogyakarta: Mitra Cendikia Press.

Mayer, R. E. (2009). Multimedia learning prinsip-prinsip dan aplikasi. (Terjemahan Teguh Wahyu Utomo). (C. U. Press, Ed.). New York.

Mishra, S., \& Reddi, U. V. (2003). Educational multimedia. New Delhi: Commonwealth Educational Media Center for Asia.

Noorhidawati, A., \& Gibb, F. (2008). How students use e-books - reading or referring? Malaysian Journal of Library $\mathcal{E}$ Information Science, 13(2), 1-14. Retrieved from http:/ / ejum.fsktm.um.edu.my/Articl 
eInformation $\cdot$ aspx? ArticleID=656

Pritchard, A. (2009). Ways of learning: learning theories and learning styles in the classroom. New York: Routledge.

Program Studi Teknologi Pendidikan FIP UNY. (2014). Kurikulum 2014 program studi teknologi pendidikan. Yogyakarta: FIP UNY.

Rusman. (2012). Belajar dan pembelajaran berbasis komputer: mengembangkan profesionalisme guru abad 21. Bandung: Alfabeta.

Schunk, D. H. (2012). Learning theories an educational perspective. Yogyakarta: Pustaka Pelajar.

Shiratuddin, N., Landoni, M., Gibb, F., \& Hassan, S. (2003). E-book technology and its potential applications in distance education. Journal of Digital Information, 3(4). Retrieved from https://journals.tdl.org/jodi/index.p hp/jodi/article/view/90/89

Siregar, E., \& Nara, H. (2014). Teori belajar dan pembelajaran. Bogor: Ghalia Indonesia.
Sungkono. (2012). Pengembangan instrumen evaluasi media modul pembelajaran. Yogyakarta.

Sungkono, Pujiriyanto, \& Hardianto, D. (2010). Kualitas produk media pembelajaran berbasis komputer mahasiswa program studi teknologi pendidikan FIP UNY. Yogyakarta. Retrieved from http://staff.uny.ac.id/sites/default/fi les/penelitian/Sungkono, M.Pd./Ringkasan penelitian PBK.pdf

Surjono, H. D. (2014). Peran teknologi pembelajaran dalam pengembangan \& peningkatan mutu SDM di era global. In Seminar Nasional Teknologi Pembelajaran, di Universitas Negeri Yogyakarta.

Winarno, Patwary, M. A. A. M., Yasid, A., Marzuki, R., Rini, S. E. S., \& Alimah, S. (2009). Teknik evaluasi multimedia pembelajaran. Yogyakarta: Genius Prima Media. 